\title{
Pre-Extension Demonstration of Improved Fodder oat Varieties in Selected Districts of Western Oromia, Ethiopia
}

\author{
*Alemayehu Kumsa, Abuye Tulu, Effa Wolteji, Mekonnen Diribsa, Wakgari Keba and Worku Temesgen \\ Oromia Agricultural Research Institute, Bako Agricultural Research Center, P.O. Box 03, Bako, Ethiopia
}

\begin{abstract}
The pre-extension demonstration of fodder oat technology with its full agronomic practices was done to demonstrate and popularize the newly released oat variety and thereby create awareness for farmers and agricultural extension agents. Two improved fodder oat varieties (Bate and Bonsa) were demonstrated on purposely selected AGP II districts namely; Boneya Boshe, Wayu Tuqa, Guto Gida, Diga, and Horro districts of East and Horro Guduru Wollega zones, respectively. One peasant association (PA) was selected purposely from each district based on forage production potential and compatibility with AGP II criteria. The experiment was demonstrated on a simple plot with a size of $10 \times 10 \mathrm{~m}$. Forage dry matter and grain yield data, and farmer perceptions and preferences were collected and analyzed by simple descriptive statistics and pair-wise ranking technique. The varieties showed remarkable variation in their dry matter and grain yield potential across the testing areas. The average dry matter yield performance of the Bate $(4.67 \mathrm{t} / \mathrm{ha})$ variety obtained from the farmer's field was relatively higher than Bonsa (4.19 t/ha) variety used as a standard check. Similarly, the average grain yield performance recorded for Bate (31.24 $\left.\mathrm{qt} \mathrm{ha}^{-1}\right)$ variety was also higher as compared to Bonsa (25.02 $\left.\mathrm{qt} \mathrm{ha}^{-1}\right)$ variety. Based on the procedure of variety evaluation and selection criteria, farmers set their criteria to evaluate, rank, and select the best variety following the real situation existing. Thus, against each of the criteria and weight attached, Bate variety was selected and ranked first for its high dry matter and grain yield, tolerance to disease and lodging, and leafiness as compared to Bonsa variety. Therefore; it is important to scale up this variety on a larger scale to improve the availability of quality feed and boost the production and productivity of livestock in the area.
\end{abstract}

Keywords: Bate, demonstration, Farmers' preference, fodder oat, herbage dry matter

DOI: $10.7176 / J N S R / 12-18-03$

Publication date:September $30^{\text {th }} 2021$

\section{Introduction}

Livestock in Ethiopia derives most of their feed from natural pasture and crop residues. CSA (2017) report on livestock feed usage and experience by smallholders indicates grazing is the major type of feed resource $(54.59 \%)$ followed by crop residues $(31.6 \%)$, hay $(6.81 \%)$, by-products $(1.53 \%)$, and improved feed $(0.31 \%)$. Grazing (natural pasture) and crop residue which contributes to the higher proportions of livestock feed resources are characterized by high fiber, low protein, minerals, and vitamins (Adugna et al., 2000). Such low-quality feeds are associated with a low voluntary intake, thus resulting in insufficient nutrient supply, low productivity, and even weight loss (Hindrichsen et al., 2004). Thus, for a more efficient and productive livestock industry, cultivation and utilization of nutritious, high-yielding, and low-cost feed technologies that are easy and available within the limit of the resources of poor farmers have paramount importance. With this view, the introduction, evaluation, and dissemination of different improved forage species have been carried so far in different parts of Ethiopia including Western Oromia.

One such potential forage species for integration into the existing livestock feeding system is the annual fodder oat (Avena sativa). Fodder oat is the most widely used annual forage crop worldwide, serving as an important source of nutrition for ruminant livestock (Andrzejewska et al., 2018). It is a well-adapted fodder crop mainly in an altitude range from 1700-3000 m.a.s.1. with 500-800 mm mean annual rainfall (Mengistu, 2008). It is an erect annual fodder crop up to $1.5 \mathrm{~m}$ tall. Oat is well adapted to a wide range of soils and relatively tolerant to moisture stress, waterlogging, and frost. It can be a good source of animal feed in the dry season if harvested at the right stage of growth, cured, and stored as hay. It is also a quick-growing, palatable, succulent, and nutritious fodder crop (Aklilu and Alemayehu 2007).

So far, introduction, evaluation, and selection of fodder oat genotypes were carried at Bako agricultural research center, and thus one variety named Bate was released. The recently released oat variety (Bate) is a good herbage yielder compared to both previously released and locally adapted varieties. However, to popularize the variety in the study area, demonstration of this variety with its production package has not been done yet at the on-farm level. Since demonstrating new technology on farmers training centers (FTC) and farmers' fields are the main tools to familiarize the farming communities with the new feed technology and thereby select the best variety with farmer participation which in turn will facilitate the adoption process, there is a strong need of undertaking further popularization of this promising forage crop. Therefore, based on this background the current study was undertaken to demonstrate and popularize improved fodder oat variety at the farmer's level 
through participatory approaches and thereby improve the availability of livestock feed in the study area.

\section{Materials and Methods}

\subsection{Site and farmer selection}

This demonstration activity was carried in purposely selected districts of East and Horro Guduru Wollega zones. Boneya Boshe, Wayu Tuqa, Diga, and Guto Gida districts were selected from east Wollega zones, while Horro district was selected from Horro Guduru zone. Selection of these districts was done based on potentiality for forage production, accessibility for proper field supervision, and compatibility with AGP II criteria. One potential PA was selected from each district following the criteria used while selecting districts.

In each PA, one farmer's research group (FRG) comprising 12 farmers was established considering $40 \%$ gender and youth balance. Then, 4 farmers were selected from each FRG as experimental farmers while the rest were considered as participants. Selection of farmers and establishment of FRG was carried in collaboration with development agents and districts expertise. The FRG members were selected based on the willingness to be held as members in FRG, accessibility for supervision, compatibility with group dynamics, and willingness to share innovations with other farmers. Moreover, farmer's selection was also done based on the availability and accessibility of land to accommodate the demonstration task, vicinity to roads to create the chance of the demonstration work to be visited by other farmers.

\subsection{Technology demonstration and implementation procedures}

Two improved fodder oat varieties (Bate) including the standard check (Bonsa) were demonstrated on wellprepared land with a plot size of $10 \mathrm{~m} * 10 \mathrm{~m}$. All agronomic practices were properly applied according to the recommendation in the center for the varieties. Seeds of both varieties were sown at a uniform seeding rate of 70 $\mathrm{kg} / \mathrm{ha}$ across locations and periods, and thus seeds were drilled in a row with a spacing of $30 \mathrm{~cm}$. Diammonium phosphate (DAP) and urea fertilizer was applied to all plots during plantation at a rate of $100 \mathrm{~kg} / \mathrm{ha}$ where the split application was used for urea The varieties were then be evaluated based on the farmer's selection criteria. During the evaluation session, farmers were assisted to jot down their evaluation criteria, which was then ordered using the pair-wise ranking techniques. Then, each variety was evaluated against the criteria ordered based on the weight attached to each parameter. Finally, the result of the evaluation was displayed to the evaluators, and discussion was held on the way ahead.

\subsection{Training and Field visit}

As part of the intervention activities, training on full agronomic practices as well as utilization systems was provided to farmers, development agents, and expertise. Finally, to evaluate the performance and final output of the varieties and share the lesson learned with the different stakeholders ' field visit was arranged in the farmers' field where demonstration work was undertaken. In the field visit, farmers, development agents, heads of the agricultural and rural development office, researchers from Bako agricultural research center, and district expertise were being invited.

\subsection{Method of data collection}

The data on grain yield and herbage dry matter yield of the varieties were collected from all plots of beneficiary farmers. Farmers' perception data of the varieties were collected using focus group discussions held during the evaluation periods. The perception data were grouped as biomass and grain yield, tolerance to lodging and disease, plant height, maturity period, leafiness, and uniformity. The farmers were responding their perception level on the relative advantage of each characteristic of the improved variety (Bate) compared to the variety used as a standard check (Bonsa)

\subsection{Method of data analysis}

Forage dry matter and grain yield data collected from all farmer's fields were analyzed by simple descriptive statistics such as mean. Data on farmer perceptions and preferences were collected and being subjected to a pairwise ranking technique.

\section{Results and Discussion}

\subsection{Provision of training}

Training is a very important tool for awareness creation and to bring improvement in filling the gap, skill, and attitude. Thus, participatory training was given to participant farmers, experts, and development agents (DA) by Animal feed and extension researchers drawn from the Bako agriculture research center. The theme of the training was mainly focused on the availability of improved fodder oat feed technology for the mid and highland agroecology of western Oromia and its production, management, and utilization systems of the technology. To create awareness about the availability and importance of improved fodder oat technology and thereby share the 
experience among farmers field visit was also held at each demonstration site. Generally, a total of 197 trainers including target farmers, experts, and DAs` were involved in the training.

Table 1. List of participants (farmers, experts, and DAs') involved in the training

\begin{tabular}{llllllll}
\hline \multirow{2}{*}{ Study locations } & Farmers & \multicolumn{7}{c}{ Experts } & DAs & Total \\
\cline { 2 - 6 } & $\mathrm{M}$ & $\mathrm{F}$ & $\mathrm{M}$ & $\mathrm{F}$ & $\mathrm{M}$ & $\mathrm{F}$ & 43 \\
BoneyaBoshe & 21 & 12 & 2 & 1 & 5 & 2 & 41 \\
WayuTuqa & 19 & 13 & 2 & 1 & 5 & 1 & 45 \\
Guto Gida & 24 & 12 & 2 & 1 & 5 & 1 & 39 \\
Diga & 18 & 11 & 3 & - & 5 & 2 & 45 \\
Horro & 23 & 12 & 2 & 2 & 4 & 2 & 197 \\
\hline Total & & & & & &
\end{tabular}

M: male; F: female; DA: development agent

\subsection{Herbage dry matter (DM) and grain yield performance of the varieties}

The herbage DM (Figure1) and grain yield (Figure 2) performance of the two oat technologies evaluated under different locations demonstrated that the varieties are performing differently across locations. The result showed that the herbage DM yield of Bate variety was higher at Horro site followed by Wayu Tuqa $>$ Boneya Boshe $>$ Guto Gida $>$ Diga with a mean yield of $4.67 \mathrm{t} / \mathrm{ha}$, while that of Bonsa variety was recorded higher at Horro site followed by Wayu Tuqa $>$ Guto Gida $>$ Boneya Boshe $>$ Diga with a mean yield of 4.19 t/ha. This variability among locations might have stemmed from a difference in the status of soil fertility and site-specific varying weather conditions.

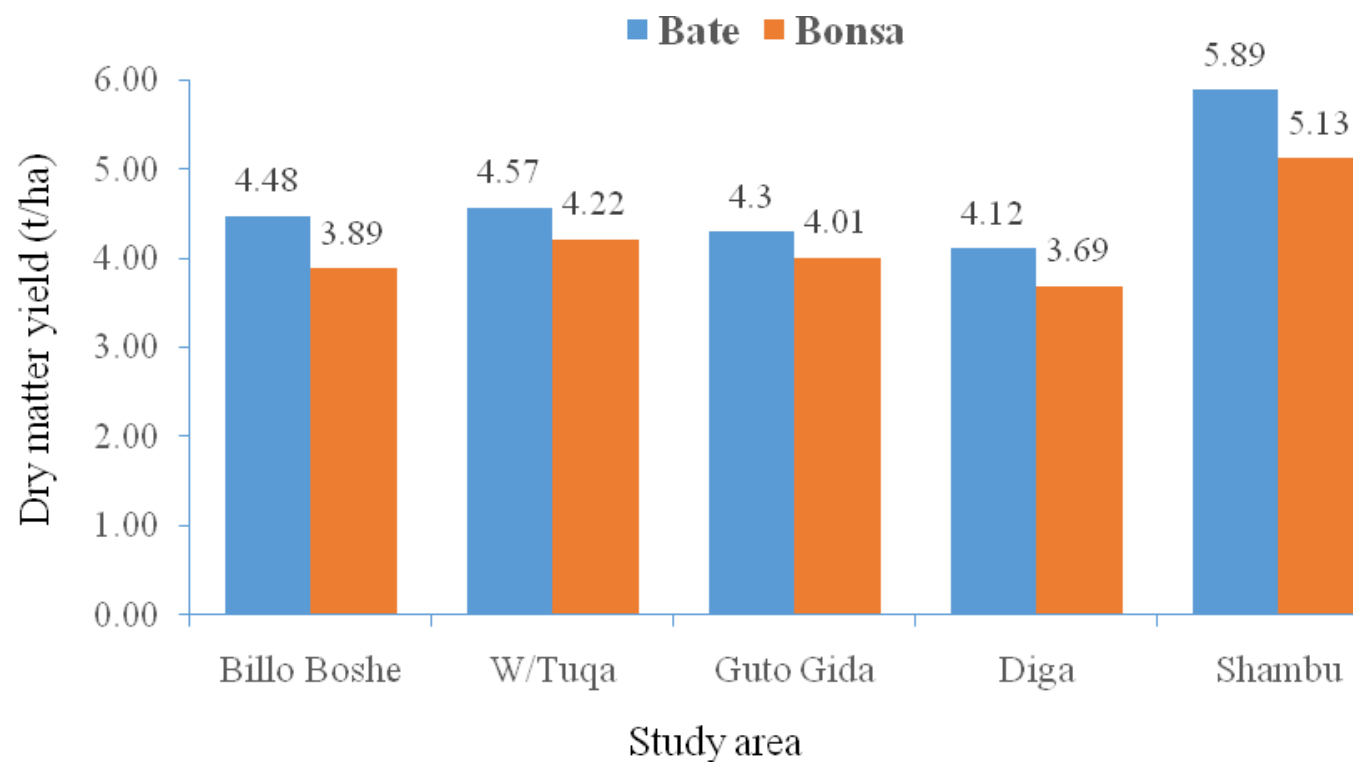

Figure 1. Dry matter yield performance of fodder oat varieties under farmer field condition

Concerning grain yield (Figure 2), the overall mean grain yield performance of Bate variety was $31.24 \mathrm{qt}$ $\mathrm{ha}^{-1}$ which was higher at Horro sites, lower at Diga but intermediate at the Boneya Boshe site. Similarly, the average grain yield recorded for the Bonsa variety was $25.02 \mathrm{qt} \mathrm{ha}^{-1}$ across locations which were higher at Horro site, lower at Diga but intermediate at the Guto Gida site. 


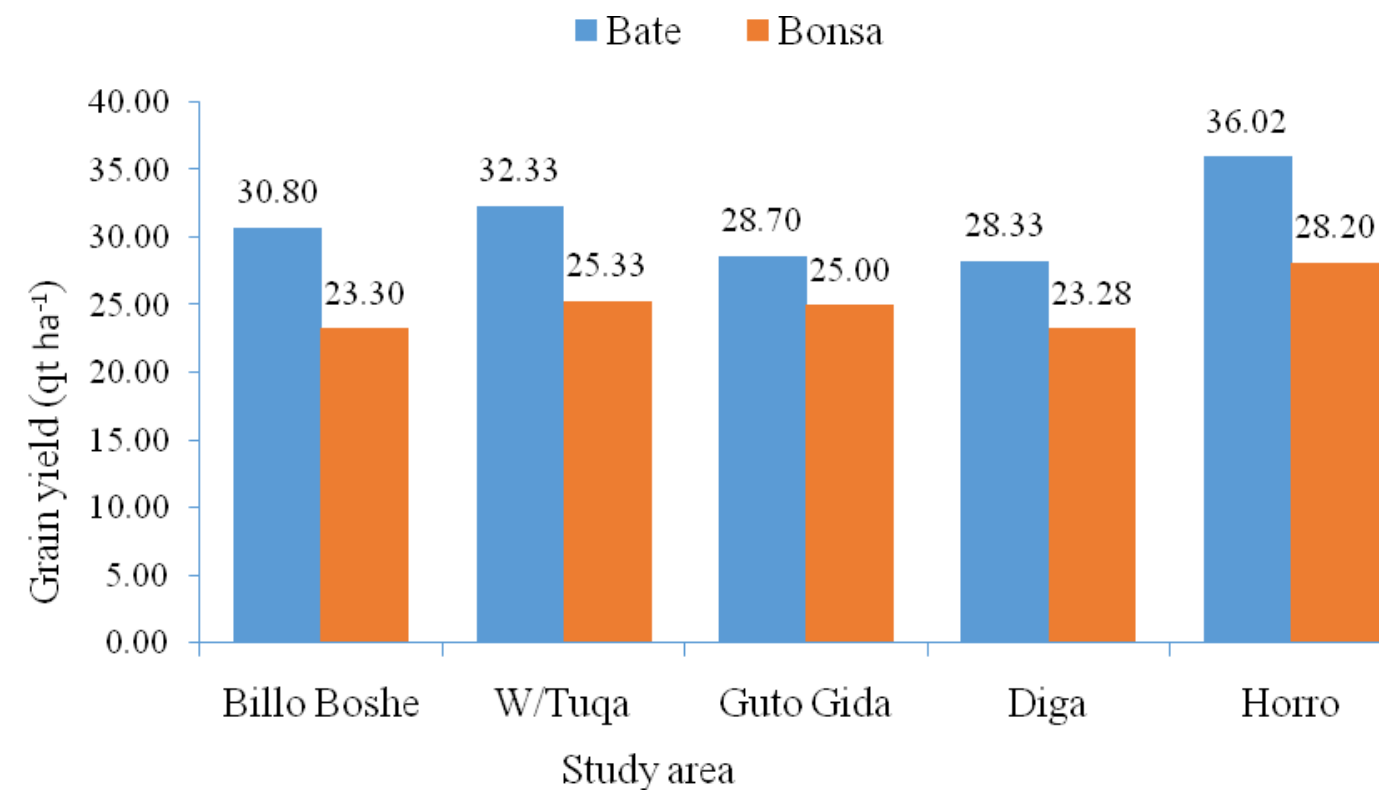

Figure 2. Grain yield performance of fodder oat varieties under farmer field condition

\subsection{Farmers' varietal preference}

Farmers' evaluation was made when the crop reaches the recommended (40-50\% flowering stage) stage for forage harvesting. Following the procedure for variety evaluation and selection criteria, farmers evaluated, ranked, and selected the best bet varieties from the demonstrated fodder oat varieties against each of the criteria and weight attached.

Table 1: Score ranking of fodder oat varieties by farmers across the districts.

\begin{tabular}{lllllll}
\hline Study locations & \multicolumn{3}{c}{ Bate } & \multicolumn{3}{c}{ Bonsa } \\
\cline { 2 - 7 } & Total Score & Mean Score & Rank & Total Score & Mean Score & Rank \\
\hline Horro & 37 & 4.62 & $1^{\text {st }}$ & 34 & 4.25 & $2^{\text {nd }}$ \\
Guto Gida & 31 & 3.87 & $2^{\text {nd }}$ & 36 & 4.5 & $1^{\text {st }}$ \\
WayuTuqa & 38 & 4.75 & $1^{\text {st }}$ & 32 & 4 & $2^{\text {nd }}$ \\
Diga & 36 & 4.5 & $1^{\text {st }}$ & 31 & 3.87 & $2^{\text {nd }}$ \\
BoneyaBoshe & 36 & 4.6 & $1^{\text {st }}$ & 31 & - & $2^{\text {nd }}$ \\
\hline Overall rank & - & - & $1^{\text {st }}$ & - & $2^{\text {nd }}$ \\
\hline
\end{tabular}

Farmers selection criteria: 1= Growth Habit, 2=Maturity Time, 3=Biomass, 4= Plant Height, 5=Leafiness, 6=Uniformity, $7=$ Disease Tolerance, and $8=$ Lodging Tolerant

According to the result in Table 1, the Bate variety was selected and ranked first by farmers from Horro, Wayu Tuqa, Diga, and Boneya Boshe districts followed by Bonsa variety. However, farmers at Guto Gida selected and ranked Bonsa at first than Bate variety. Based on the overall mean score, Bate variety was preferred and selected by farmers' across the study area, and thus this variety will be proposed for further scaling up.

From the evaluation result, the reasons for selecting as the best variety and suited utmost by farmers at large between the demonstrated varieties against the weight attached to each of the traits was summarized and presented in Table 2 below.

Table 2. Varietal ranking based on farmers' selection criteria

\begin{tabular}{|l|l|l|l|}
\hline No & Varieties & Rank & Reasons \\
\hline 1 & Bate & $1^{\text {st }}$ & $\begin{array}{l}\text { High biomass yield, disease tolerant, lodging tolerant, very good plant height/ } \\
\text { stand, high in leafiness, very good uniformity }\end{array}$ \\
\hline 2 & Bonsa & $2^{\text {nd }}$ & $\begin{array}{l}\text { Low biomass yield, disease tolerant, lodging tolerant, medium plant height/stand, } \\
\text { medium in leafiness, very good in uniformity }\end{array}$ \\
\hline
\end{tabular}

\section{Conclusion and Recommendation}

Two improved fodder oat varieties including check were demonstrated in five districts of East and Horro Guduru Wollega zones during the year 2019. Biomass yield, disease and lodging tolerance, plant height/stand, leafiness and uniformity were identified and used as selection criteria across all the locations to select the best performing 
varieties. The overall mean herbage dry matter yield of the Bate variety was $4.67 \mathrm{t} /$ ha which is relatively higher than the Bonsa variety which gave $4.19 \mathrm{t} / \mathrm{ha}$. Similarly, the average grain yield performance of the Bate (31.24 qt $\mathrm{ha}^{-1}$ ) variety was also higher than that of the Bonsa variety (25.02 qt ha-1). Generally, participant farmers' participated in participatory evaluation and selection of the varieties reasonably evaluated, ranked, and selected Bate as the first best preferred and suitable variety with the real existing situation on the ground, and thus this variety will be proposed for further scaling up.

\section{References}

Adugna Tolera, Merkel, R.C., Goetsch, A.L., Sahlu T. and Negesse T. 2000. Nutritional constraint and future prospects for goat production in East Africa. In: Opportunities and Challenges of Enhancing Goat Production in East Africa, Conference held at Debub University, Awassa, Ethiopia, November 10-12, 2000, pp. 43-57.

Akililu M. and Alemayehu M. 2007. Measurements in pasture and forage cropping systems. Technical manual 18, EIAR, Addis Ababa, Ethiopia. Pg 41.

Andrzejewska J., Contreras-Govea F.E., Pastuszka A., Kotwica K., Albrecht K.A.2019. Performance of oat (Avena sativa L.) sown in late summer for autumn forage production in Central Europe. Grass Forage Sci. 74: 97-103:https://doi.org/10.1111/gfs.12400

CSA (Central Statistical Agency). 2017. Agricultural Sample Survey, Volume II: Report on Livestock and livestock characteristics (Private peasant holdings). Statistical Bulletin 585: Central Statistical Agency (CSA), Federal Democratic Republic of Ethiopia, Addis Ababa.

Hindrichsen, I.K., Osuji, P.O., Odenyo, A.A., Madsen, J. and Hvelplund, T. 2004. Effects of supplementation of maize stover with foliage of various tropical multipurpose trees and Lablab purpureus on intake, rumen fermentation, digesta kinetics, and microbial protein supply of sheep. Animal Feed Science and Technology, 113:83-96.

Mengistu S. 2008. Forage development for sheep and goats. Sheep and goat production handbook for Ethiopia. Ethiopia Sheep and Goat Productivity Improvement Program. 